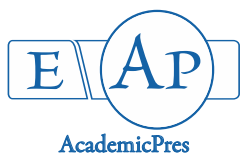

Ahmadu R et al. (2020)

Notulae Scientia Biologicae 12(1):189-195

DOI: $10.15835 / \mathrm{nsb} 12110529$

Research Article

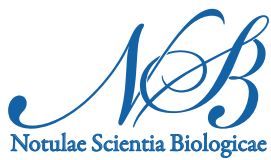

\title{
Comparative effects of some soil amendments on the agronomic performance of maize varieties in a low fertile soil
}

\author{
Rimande AHMADU ${ }^{1}$, Kolawole LAW-OGBOMO ${ }^{2 *}$, \\ Sunday A. OGEDEGBE ${ }^{2}$ \\ ${ }^{1}$ Federal University, Faculty of Agriculture and Life Science, Department of Crop Production and Protection, Wukari, \\ Nigeria; rimandeahmadu@yahoo.com \\ ${ }^{2}$ University of Benin, Faculty of Agriculture, Department of Crop Science, Benin City, \\ Nigeria; edomwonyi.law-ogbomo@uniben.edu (*correspondingauthor); sundayogedegbe@uniben.edu
}

\begin{abstract}
A field study was conducted in cropping seasons to determine the comparative effects of some soil amendments on postharvest soil chemical properties and performance of maize (Zea mays L.) in humid low fertile soil. The experiment was laid out in $3 \times 4$ split plot arrangement, fitted into a randomized complete block design with three replications. The main plots were maize varieties ('SUWAN-I-SR', 'Oba 98' and 'Uselu' local maize) and the subplots were soil amendments (control, poultry manure, cattle manure and NPK). Data were collected on growth parameters (plant heights $(\mathrm{cm})$, number of leaves, leaf area index and stem girth) at 50\% silking stage. At harvest, data were collected on grain yield components and several soil chemical properties. The results showed that the variety had significant $(\mathrm{p}<0.05)$ effect on growth and yield performance of maize. Fertilizer application significantly $(\mathrm{p}<0.05)$ improved maize vegetative characters. The fertilized plants were higher in all the parameters accessed than the unfertilized plants. 'SUWAN-1-SR' had the highest grain yield $\left(2.49 \mathrm{tha}^{-1}\right)$. The highest grain yield of 2.22 and $2.11 \mathrm{t} \mathrm{ha} \mathrm{a}^{-1}$ were produced from plants fertilized with NPK and poultry manure, respectively. Variety significantly $(\mathrm{p}<0.05)$ influenced organic carbon, available $\mathrm{P}$, exchangeable acidity $\left(\mathrm{H}^{+}\right.$and $\left.\mathrm{Al}^{3+}\right)$. Poultry and cattle manures improved soil fertility through increase in soil $\mathrm{pH}$, organic carbon and exchangeable cations. Since NPK and poultry manure had the highest grain yield, poultry manure could be used as viable option for maize production in low fertile soil environment, due to low cost and for environmental cleanliness.
\end{abstract}

Keywords: fertilizer types; varieties; vegetative growth; yield components

\section{Introduction}

Maize (Zea mays L.) is the third most important cereal crop after wheat and rice (Mohamed and Hassan, 2011). The crop is commonly cultivated worldwide, including in the tropics and warm sub-tropics. It is one of the most important cereals, both for human and animal consumption and is grown for grain and forage. The world production of the crop is of about 785 million tons of grain from about 158 million ha (FAO, 2009). In Nigeria, maize is an important food, fodder and industrial crop grown both commercially 
and at subsistence level. Maize as food is used for the production of indigenous and commercial food products (Agba et al., 2012).

The crop productivity is low in Nigeria as compared to other countries due to low nutrient status of most tropical soils and the use of unimproved varieties among other factors. Most soils in humid tropics are intensely weathered, leached and intensively cultivated, leading to impoverished soil (Akanbi and Togun, 2002). Hence, it lacks the capacity to support plant growth to produce optimally. The inherently low fertility status of the soil had resulted in poor crop performance in the field. Most farmers are not aware that new improved varieties exist, which are adapted to their locality. Farmers use the improved varieties without considering the type of location and what they were bred for. Non-use of improved varieties is hindrance to high crop performance.

Efforts aimed at obtaining high yield of maize would necessitate the augmentation of the nutrient status of the soil to meet the crop's requirement for optimum productivity and maintenance of soil fertility. Increasing the nutrient status of the soil may be achieved by boosting the soil nutrient content either with the use of inorganic fertilizers such as NPK or through the use of organic materials such as poultry or cattle manures. The maize crop requires an adequate supply of nutrients, particularly nitrogen, phosphorus and potassium for optimum growth and yield (Agba et al., 2012). Inorganic fertilizer exerts a strong influence on plant growth, development and yield (Stefano et al., 2004). The availability of sufficient growth nutrients from inorganic fertilizers could lead to improved soil fertility. However, due to high cost and scarcity of inorganic fertilizer, most farmers cannot afford its usage and under intensive cultivation, it is often associated with soil acidity and nutrient imbalance (Ojeniyi, 2000). This had diverted the attention of agronomists towards making use of organic nutrients for improving soil fertility that allow for profitable crop production (Somani and Totawat, 1996). Contradictory results about positive and negative effects of soil amendments (both organic and inorganic) have been found in literature.

There is lack of research work on the evaluation of soil amendments on improved and local varieties of maize in the study area. However, there is need to identify the best variety and the most appropriate soil amendment thereby. Hence, the present study was conducted to evaluate the comparative effects of some soil amendments on performance of several maize varieties in an ultisols of Benin City, Edo State, Nigeria.

\section{Materials and Methods}

\section{Description of study location}

The study was conducted in 2015 and 2016 at the experimental site of the Faculty of Agriculture, University of Benin, Benin City, Edo State, Nigeria. The site is situated at latitude $6^{\circ} 44$ and $7^{\circ} 34$ and longitude $6^{\circ} 5$ and $6^{\circ} 43$ with an altitude of $162 \mathrm{~m}$ above the sea level. The temperature at maximum was about $30^{\circ} \mathrm{C}$ and minimum of $24^{\circ} \mathrm{C}$. Mean annual rainfall is about $2,300 \mathrm{~mm}$.

\section{Experimental design and cultural practices}

The experimental site measuring $23 \times 21.5 \mathrm{~m}$ was cleared, ploughed and harrowed. Tapes, pegs, mallet and ropes were used to demarcate the area into 3 blocks of 36 subplots. The experiment was laid out in a $3 \times 4$ split-plot arrangement fitted into randomized complete block design (RCBD) and replicated three times. The main plots were the maize varieties ('SUWAN-1-SR', 'Oba 98' and 'Uselu' which is local) and the subplots were the soil amendments (control, poultry manure, cattle manure and NPK 15:15:15 fertilizer). Each of the plots measured $2 \times 5 \mathrm{~m}$ with a spacing of $0.5 \mathrm{~m}$ apart between plots and $1 \mathrm{~m}$ space between blocks. Poultry and cattle manures were applied on the subplots in each main plot at $15 \mathrm{t} \mathrm{ha}^{-1}$ four weeks prior to sowing for equilibration. Maize seeds of improved varieties ('SUWAN-I-SR' and 'Oba 98') sourced from International Institute of Tropical Agriculture (IITA) was used, while the local variety was bought from Uselu market, Benin-City, Edo State, Nigeria. Two maize seeds were sowed per whole and spaced $75 \times 25 \mathrm{~cm}$. Two weeks after germination, they were thinned down to one plant per stand. NPK 15:15:15 at $400 \mathrm{~kg} \mathrm{ha}^{-1}$ 
was applied in two equal splits at 2 weeks after sowing (WAS) and at $50 \%$ tasseling. Weeding was done manually with hoe at 2 WAS and subsequently at when due. Harvesting was done when maize ears have fully turned brown and dry at physiological maturity indicated by block layer formation. Harvested ears were air dried to $12 \%$ moisture content.

\section{Soil sample collection, organic manure and laboratory analyses}

Soil sampling were randomly collected from 36 plots at a depth of $0-15 \mathrm{~cm}$ using auger and bulked to form composite sample before fertilizer application and cropping with maize. After harvest, another 36 soil samples were collected separately from all the plots. The soil samples were air-dried and sieved through $2 \mathrm{~mm}$ sieve and used for soil physical and chemical properties determination. However, after harvest, soil samples from all plots were analysed for their chemical properties only. All the soil samples were collected in small polythene bags and labeled accordingly. Before the application of organic manure (poultry and cattle manures), they were sampled and air-dried in polythene bags for analysis.

Particle size analysis was determined by hydrometer method (Gee and Or, 2002). Soil pH was estimated potentiometrically in a glass electrode in deionized at a soil/solution 1:1. Organic carbon was determined by wet dichromate acid oxidation method (Page, 1982). Total nitrogen was determined by micro Kjedahl digestion method (Bremner and Mulvancy, 1982). Available phosphorus was extracted using calcium chloride extraction method (Houba et al., 2000).

Exchangeable bases $\left(\mathrm{Ca}, \mathrm{K}, \mathrm{Mg}\right.$ and $\mathrm{Na}$ ) were extracted using IN ammonium acetate $\left(\mathrm{NH}_{4} \mathrm{OAC}\right)$ solution at $\mathrm{pH}$ 7.0. Calcium and magnesium content were determined by volumetrically ethylene diaminetetra-acetic acid ((EDTA) titration procedure of Black (1965), while potassium and sodium using flame photometer. Exchangeable acidity was determined by titration method (Anderson and Ingram, 1993). For lead determination, $2 \mathrm{~g}$ of each sample was digested using $20 \mathrm{ml}$ of concentrated mixture of hydrogen nitrate $\left(\mathrm{HNO}_{3}, \mathrm{HClO}_{4}\right)$ and $\mathrm{H}_{2} \mathrm{SO}_{4}$ in 2:1:1 ratio on temperature hot plate. When the volume was reduced with clear digested solution, the content was allowed to cool and transferred to a $50 \mathrm{ml}$ volumetric flask. The volume was made up to the mark then the lead was determined by atomic absorption spectrophotometer (AAS).

Organic fertilizers (cattle and poultry manures) were analyzed for $\mathrm{pH}$, organic carbon, nitrogen, phosphorus, potassium, calcium, magnesium and lead. $\mathrm{pH}$ was determined at 1:1 soil to water ratio using manure to water ratio, by using digital glass electrode $\mathrm{pH}$ meter. Organic carbon was determined by the wet dichromate acid oxidation method (Page, 1982). Total nitrogen was determined by micro Kjedahl digestion method (Bremner and Mulvancy, 1982). Available phosphorus was extracted using calcium chloride extraction method (Houba et al., 2000). Exchangeable base (Ca, $\mathrm{K}, \mathrm{Mg}$ and $\mathrm{Na}$ ) were extracted using IN ammonium acetate $\left(\mathrm{NH}_{4} \mathrm{OAC}\right)$ solution at $\mathrm{pH}$ 7.0. Calcium and magnesium content were determined volumetrically with ethylene diaminetetra-acetic acid ((EDTA) titration procedure (Black, 1965), while potassium using flame photometer. The lead, chromium and cadmium were determined by atomic absorption spectrophotometer (AAS).

\section{Data collection}

Data were collected on five randomly selected plants from the inner row of each plot on plant height, number of leaves, leaf area and stem girth at 50\% silking. Plant height was measured in $\mathrm{cm}$ from the ground level to the last leaf before tassel. Stem girth was measured at $5 \mathrm{~cm}$ above ground level on each sampled plant with the use of Vernier caliper. Number of leaves refers to the total count of the fully expanded leaves per plant. Leaf area index (LAI) was determined by measuring the length and width of the sampled leaves using a meter rule calibrated in $\mathrm{cm}$ and multiplied with a factor of 0.75 and the number of leaves to observed the leaf area of the plant (Remison, 1997). From the leaf area, LAI was computed as: LAI =Leaf area/Land area (Remison, 1997).

At harvest, data were collected on number of kernel row $\operatorname{cob}^{-1}$, number of kernels in a row, 1,000 grain weight and grain yield. The number of kernel rows $\mathrm{cob}^{-1}$ was obtained by counting the number of kernel row 
of each of the sampled plant and average computed. The number of kernels in each row of the sampled plants was counted and average computed. Grains of five randomly selected plants were randomly collected from each plot; 1,000 grains were counted out, weighed and expressed in grams. Grains of five randomly selected plants were weighed separately, sum up and expressed in $\mathrm{t} \mathrm{ha}^{-1}$.

Data analysis

Data collected were subjected to combined analysis of variance by the use of GENSTAT programme, version 8.1 (GENSTAT, 2005). Significant differences among treatment means separated using least significant difference (LSD) at $5 \%$ level of significant.

\section{Results}

Physical and chemical properties of the experimental site before cropping with maize and the chemical composition of organic fertilizers

The physical and chemical properties of the soil prior to cropping with maize and chemical composition of cattle and poultry manures are presented in Table 1. Soil samples of 2015 and 2016 were textually sandy loam. The soils were highly acidic with moderate organic carbon. However, total nitrogen, available phosphorus. Exchangeable cations (calcium, magnesium, potassium and sodium) were low. Similarly, the exchangeable acidity $\left(\mathrm{H}^{+}\right.$and $\left.\mathrm{Al}^{3+}\right)$ were also present in both soil samples.

The $\mathrm{pH}$ of poultry manure was neutral, while that of cattle manure was slightly acidic. Both contained high amount of organic carbon and appreciable quantities of total nitrogen, available $\mathrm{P}$ and exchangeable cations. The C:N ratio for both poultry manure and cattle manure were low. Both organic fertilizers also contained lower amount of $\mathrm{Pb}$ and exchangeable acidity $\left(\mathrm{H}^{+}\right.$and $\left.\mathrm{Al}^{3+}\right)$.

\section{Growth of maize}

The results of the effects of varieties and soil amendments on growth of maize at $50 \%$ silking are presented in Table 2. Variety had significant $(\mathrm{p}<0.05)$ effect on plant height as the shortest plants were observed in 'Uselu' local variety and the tallest plants $(128.00 \mathrm{~cm})$ in 'Oba 98 '. This trend was also repeated for stem girth and LAI. Higher number of leaves was observed on 'SUWAN-1-SR' and 'Oba 98' than on 'Uselu' local varity.

Soil amendment had significant $(\mathrm{p}<0.05)$ effect on plant height. All plants treated with soil amendments were significantly $(\mathrm{p}<0.05)$ taller than control plants. The tallest and thickest plants were observed on plots treated with poultry manure. Poultry manure, cattle manure and NPK had similar values of number of leaves and LAI, but significantly $(\mathrm{p}<0.05)$ higher than the values unfertilized plants.

\section{Grain yield and its components of maize}

The results of the effect of varieties and soil amendments on the grain yield and its components are shown in Table 3. 'SUWAN-1-SR' had the highest number of kernel rows $\operatorname{cob}^{-1}$, number of kernels row ${ }^{-1}$ and grain yield, whereas 1,000 grain weight was significantly higher in 'SUWAN-1-SR' and 'Oba 98' than 'Uselu' local. Soil amendment application had significant effect $(\mathrm{p}<0.05)$ on grain yield and its components. Number of kernel rows $\mathrm{cob}^{-1}$ ranged from 10 for untreated control to 13 for plants treated with cattle manure. All soil amendment treated plants had similar number of kernels in a row and 1,000 grain weight, but significantly $(p<0.05)$ higher than untreated plants. The higher grain yields were observed on plants fertilized with poultry manure $\left(2.11 \mathrm{t} \mathrm{ha}^{-1}\right)$ and NPK $\left(2.22 \mathrm{tha}^{-1}\right)$, while the least grain yield was observed on control $\left(1.07 \mathrm{t} \mathrm{ha}^{-1}\right)$. 
Table 1. Physical and chemical properties of the experimental site before cropping with maize and chemical composition of organic fertilizers

\begin{tabular}{|c|c|c|c|c|}
\hline \multirow{2}{*}{ Parameter } & \multicolumn{2}{|c|}{ Soil } & \multicolumn{2}{c|}{ Organic fertilizer } \\
\cline { 2 - 4 } & 2015 & 2016 & Poultry manure & Cattle manure \\
\hline Particle $\left(\mathrm{g} \mathrm{kg}^{-1}\right)$ & & & & NA \\
\hline Sand & 880.00 & 876.00 & NA & NA \\
\hline Silt & 56.00 & 58.20 & NA & NA \\
\hline Clay & 64.00 & 65.80 & NA & 32.25 \\
\hline pH & 4.40 & 4.60 & 7.00 & 10.40 \\
\hline Organic carbon $\left(\mathrm{g} \mathrm{kg}^{-1}\right)$ & 20.65 & 21.40 & 35.41 & 3.10 \\
\hline Total nitrogen $\left(\mathrm{g} \mathrm{kg}^{-1}\right)$ & 0.96 & 0.88 & 16.50 & 5.70 \\
\hline C:N & 21.51 & 24.32 & 2.15 & 0.51 \\
\hline Available phosphorus $\left(\mathrm{mg} \mathrm{kg}^{-1}\right)$ & 8.22 & 7.96 & 9.64 & 1.80 \\
\hline Exchangeable cation $\left(\mathrm{cmol} \mathrm{kg}^{-1}\right)$ & & & & 0.83 \\
\hline Calcium & 0.42 & 0.46 & 0.68 & 0.51 \\
\hline Magnesium & 0.21 & 0.28 & 2.15 & \\
\hline Potassium & 0.30 & 0.25 & 1.06 & 0.03 \\
\hline Sodium & 0.18 & 0.16 & 0.54 & 0.64 \\
\hline Exchangeable acidity $\left(\mathrm{cmol} \mathrm{kg}^{-1}\right)$ & & & & 0.24 \\
\hline Al & 0.81 & 0.62 & 0.03 & 0.08 \\
\hline Pb (mg kg-1) & 0.40 & 0.10 & 0.24 & \\
\hline
\end{tabular}

Table 2. Effects of the studied maize varieties and fertilizer types on the growth of maize

\begin{tabular}{|c|c|c|c|c|c|c|c|c|c|c|c|c|}
\hline Treatment & \multicolumn{3}{|c|}{ Plant height $(\mathrm{cm})$} & \multicolumn{3}{c|}{ Stem girth $(\mathrm{cm})$} & \multicolumn{3}{c|}{ Number of leaves } & \multicolumn{3}{c|}{ Leaf area index } \\
\hline & 2015 & 2016 & Combined & 2015 & 2016 & Combined & 2015 & 2016 & Combined & 2015 & 2016 & Combined \\
\hline Variety & & & & & & & & & & & & \\
\hline 'SUWAN-1-SR' & 113.80 & 218.00 & 165 & 6.06 & 6.090 & 6.09 & 16 & 15 & 15 & 2.98 & 3.96 & 3.45 \\
\hline 'Oba 98' & 110.20 & 146.00 & 128 & 5.72 & 6.080 & 5.90 & 16 & 14 & 15 & 2.58 & 3.73 & 3.16 \\
\hline 'Uselu' local & 90.40 & 120.00 & 105 & 4.92 & 6.040 & 5.48 & 14 & 14 & 14 & 1.96 & 3.58 & 2.77 \\
\hline LSD $_{(0.05)}$ & 13.450 & 17.000 & 15.225 & 0.293 & $\mathrm{~ns}$ & 0.647 & 0.6 & $\mathrm{~ns}$ & 0.7 & 0.445 & $\mathrm{~ns}$ & 0.891 \\
\hline Fertilizer types & & & & & & & & & & & & \\
\hline Control & 86.60 & 108.00 & 43.30 & 5.04 & 5.41 & 5.25 & 14 & 14 & 14 & 1.92 & 2.77 & 2.34 \\
\hline Poultry manure & 122.00 & 281.00 & 204.20 & 6.04 & 6.75 & 6.40 & 15 & 15 & 15 & 2.47 & 4.39 & 3.43 \\
\hline Cattle manure & 109.40 & 135.00 & 122.20 & 5.59 & 6.01 & 5.80 & 15 & 15 & 15 & 2.53 & 3.68 & 3.11 \\
\hline NPK $^{104.60}$ & 127.70 & 123.40 & 5.61 & 6.11 & 5.86 & 16 & 15 & 15 & 3.11 & 4.13 & 3.62 \\
\hline LSD $_{(0.05)}$ & 13.450 & 17.000 & 15.26 & 0.293 & 1.00 & 0.647 & 0.6 & $\mathrm{~ns}$ & 0.7 & 0.445 & 1.337 & 0.574 \\
\hline Interaction & $\mathrm{ns}$ & $\mathrm{ns}$ & $\mathrm{ns}$ & $\mathrm{ns}$ & $\mathrm{ns}$ & $\mathrm{ns}$ & $\mathrm{ns}$ & $\mathrm{ns}$ & $\mathrm{ns}$ & $\mathrm{ns}$ & $\mathrm{ns}$ & $\mathrm{ns}$ \\
\hline
\end{tabular}

ns-not significant at $5 \%$ level of significant

Table 3. Effects of the studied maize varieties and fertilizer types on the growth of maize

\begin{tabular}{|c|c|c|c|c|c|c|c|c|c|c|c|c|}
\hline \multirow[t]{2}{*}{ Treatment } & \multicolumn{3}{|c|}{ No. of kernel row in a cob } & \multicolumn{3}{|c|}{ No. of kernel in a row } & \multicolumn{3}{|c|}{1000 grain weight $(\mathrm{g})$} & \multicolumn{3}{|c|}{ Grain yield $\left(\mathrm{t} \mathrm{ha}^{-1}\right)$} \\
\hline & 2015 & 2016 & Combined & 2015 & 2016 & Combined & 2015 & 2016 & Combined & 2015 & 2016 & Combined \\
\hline \multicolumn{13}{|l|}{ Variety } \\
\hline 'SUWAN-1-SR' & 11 & 13 & 12 & 11 & 18 & 14 & 230.3 & 215.00 & 222.65 & 1.75 & 3.22 & 2.49 \\
\hline 'Oba 98' & 11 & 12 & 11 & 10 & 13 & 11 & 225.5 & 204.00 & 214.75 & 1.13 & 1.70 & 1.42 \\
\hline 'Uselu' local & 11 & 11 & 11 & 7 & 13 & 10 & 163.3 & 197.90 & 180.60 & 1.10 & 1.70 & 1.40 \\
\hline $\operatorname{LSD}_{(0.05)}$ & ns & 0.6 & 0.7 & ns & 3.4 & 2.3 & 36.43 & 19.180 & 27.805 & 0.960 & 0.789 & 0.524 \\
\hline \multicolumn{13}{|l|}{ Fertilizer types } \\
\hline Control & 10 & 10 & 10 & 7 & 9 & 8 & 154.9 & 175.50 & 165.20 & 0.93 & 1.20 & 1.07 \\
\hline Poultry manure & 11 & 13 & 12 & 9 & 18 & 13 & 2249 & 221.80 & 223.35 & 1.18 & 3.04 & 2.11 \\
\hline Cattle manure & 14 & 12 & 13 & 9 & 15 & 12 & 213,6 & 204.80 & 209.20 & 1.29 & 2.07 & 1.68 \\
\hline NPK & 11 & 12 & 11 & 12 & 16 & 13 & 332.2 & .223 .00 & 227.60 & 1.91 & 2.52 & 2.22 \\
\hline $\operatorname{LSD}_{(0.05)}$ & 0.700 & 0.6 & 0.7 & 12 & 3.4 & 2.3 & 36.43 & 19.180 & 27.805 & 0.451 & 0.489 & 0.524 \\
\hline Interaction & $\mathrm{ns}$ & ns & ns & 3.9 & ns & $\mathrm{ns}$ & 25.35 & ns & $\mathrm{ns}$ & 0.960 & 0.787 & ns \\
\hline
\end{tabular}




\section{Postharvest soil chemical properties as influenced by variety and fertilizer type}

The results of the postharvest soil chemical properties as influenced by varieties and soil amendments are presented in Table 4. Variety only had significant effect $(\mathrm{p}<0.05)$ on organic $\mathrm{C}$, available phosphorus and exchangeable acidity $\left(\mathrm{H}^{+}\right.$and $\left.\mathrm{Al}^{3+}\right)$. Higher organic $\mathrm{C}$ was observed on 'SUWAN-1-SR' and 'Oba 98' plots than 'Uselu' local plots. The highest available P was observed on 'SUWAN-1-SR' plots, followed by 'Uselu' local and 'Oba 98' in that order. Exchangeable $\mathrm{H}^{+}$ranged between 0.22 and $0.43 \mathrm{cmol} \mathrm{kg}^{-1}$ for 'Oba 98' and 'SUWAN-1-SR', respectively. 'SUWAN-1-SR' was not significantly $(\mathrm{p}>0.05)$ different from 'Uselu' local. Exchangeable $\mathrm{Al}^{3+}$ was more abundant on 'SUWAN-1-SR' plots and less on 'Oba 98' and 'Uselu' local.

The soil pH ranged between 4.84 (control) and 5.48 (cattle manure). However, cattle manure and poultry manure had similar $\mathrm{pH}$ values. Organic $\mathrm{C}$ contents were higher on manures treated plots than cattle manure $\left(20.44 \mathrm{~g} \mathrm{~kg}^{-1}\right)$. The organic carbon contents of NPK $\left(15.90 \mathrm{~g} \mathrm{~kg}^{-1}\right)$ and control $\left(14.74 \mathrm{~g} \mathrm{~kg}^{-1}\right)$ plots were comparable and the least. The highest total $\mathrm{N}$, available $\mathrm{P}$ and exchangeable $\mathrm{K}$ were observed in NPK treated plots and the least were observed on control plots.

Exchangeable $\mathrm{Ca}^{2+}$ and $\mathrm{Mg}^{2+}$ were more abundant on poultry and cattle manures treated plots and least on control and NPK plots. Exchangeable $\mathrm{Na}^{+}$concentration was highest in poultry manure plots $(0.22$ $\left.\mathrm{cmol} \mathrm{kg}{ }^{-1}\right)$ and least on control plots. NPK plots exhibited the most abundant exchangeable $\mathrm{H}^{+}(0.41 \mathrm{cmol} \mathrm{kg}$ $\left.{ }^{1}\right)$, which was statistically comparable to control plots and the least were observed on poultry $\left(0.27 \mathrm{cmol} \mathrm{kg}^{-1}\right)$ and cattle $\left(0.23 \mathrm{cmol} \mathrm{kg}^{-1}\right)$ plots. Exchangeable $\mathrm{Al}^{3+}$ was most abundant on NPK and poultry manure treated plots and least on control plots. The most contaminated heavy metal $(\mathrm{Pb})$ plot was cattle manure and completely absent in control plots.

The interaction of varieties and soil amendments type on soil chemical properties was only significant on $\mathrm{pH}$, available $\mathrm{P}$, exchangeable cations $\left(\mathrm{Mg}^{2+}\right.$ and $\left.\mathrm{Na}^{+}\right)$and $\mathrm{Pb}$. The highest soil $\mathrm{pH}$ (5.48) was observed from 'Oba 98' plots treated with cattle manure (Figure 1). 'SUWAN-1-SR' plots treated with NPK had the highest available $\mathrm{P}$ (16.64 $\mathrm{mg} \mathrm{kg}^{-1}$ ) (Figure 2). The highest $\mathrm{Mg}$ content was observed from 'SUWAN-1-SR' and 'Oba 98' plots treated with poultry and cattle manures, respectively (Figure 3). Figure 4 shows the interaction effect of variety and fertilizer type on exchangeable Na plot. Plot cropped with 'SUWAN-1-SR' and 'Uselu' local treated with poultry manure had the highest exchangeable $\mathrm{Na}^{+}$concentration $(0.23 \mathrm{cmol} \mathrm{kg}$ ' $\left.{ }^{1}\right)$. $\mathrm{Pb}$ was most abundant in plots cropped with 'Uselu' local fortified with cattle manure $\left(0.22 \mathrm{mg} \mathrm{kg}{ }^{-1}\right)$ (Figure 5).

Table 4. Effects of maize variety and fertilizer type on the postharvest soil chemical properties

\begin{tabular}{|c|c|c|c|c|c|c|c|c|c|c|c|c|}
\hline Time & Treatment & $\mathrm{pH}$ & $\begin{array}{c}\text { Organic } \\
\mathrm{C}\end{array}$ & Total N & $\begin{array}{c}\text { Available } \\
\text { P }\end{array}$ & \multicolumn{4}{|c|}{$\begin{array}{c}\text { Exchangeable cations } \\
\left(\mathrm{cmol} \mathrm{kg}^{-1}\right)\end{array}$} & \multicolumn{2}{|c|}{$\begin{array}{c}\text { Exchangeable acidity } \\
\left(\mathrm{cmol} \mathrm{kg}^{-1}\right)\end{array}$} & \multirow{2}{*}{$\begin{array}{c}\text { Heavy metal } \\
\left(\mathrm{mg} \mathrm{kg}^{-1}\right)\end{array}$} \\
\hline \multirow{13}{*}{$\begin{array}{l}\text { Early season } \\
2015\end{array}$} & & & $\left(\mathrm{~g} \mathrm{~kg}^{-1}\right)$ & $\left(\mathrm{g} \mathrm{kg}^{-1}\right)$ & $\left(\mathrm{mg} \mathrm{kg}^{-1}\right)$ & $\mathrm{Ca}$ & $\mathrm{Mg}$ & $\mathrm{K}$ & $\mathrm{Na}$ & $\mathrm{H}$ & $\mathrm{Al}$ & \\
\hline & Variety & & & & & & & & & & & \\
\hline & 'SUWAN-I-SR' & 5.13 & 19.63 & 1.41 & 10.15 & 0.55 & 0.26 & 1.05 & 0.16 & 0.57 & 0.17 & 0.11 \\
\hline & 'Oba 98' & 5.23 & 18.40 & 1.45 & 9.18 & 0.54 & 0.27 & 1.01 & 0.19 & 0.28 & 0.08 & 0.11 \\
\hline & 'Uselu' local & 5.10 & 17.39 & 1.50 & 9.96 & 0.49 & 0.24 & 1.12 & 0.20 & 0.28 & 0.07 & 0.07 \\
\hline & $\operatorname{LSD}_{(0.05)}$ & $\mathrm{ns}$ & 0.645 & ns & 0.636 & ns & ns & 0.063 & ns & 0.153 & 0.041 & ns \\
\hline & Fertilizer types & & & & & & & & & & & \\
\hline & Control & 4.77 & 14.36 & 0.76 & 5.16 & 0.41 & 0.21 & 0.26 & 0.12 & 0.43 & 0.13 & 0.01 \\
\hline & Poultry manure & 5.28 & 22.85 & 1.20 & 9.14 & 0.59 & 0.28 & 0.61 & 0.22 & 0.37 & 0.12 & 0.07 \\
\hline & Cattle manure & 5.56 & 20.66 & 1.08 & 7.80 & 0.65 & 0.31 & 0.57 & 0.20 & 0.29 & 0.08 & 0.23 \\
\hline & NPK & 5.01 & 16.01 & 2.76 & 16.68 & 0.46 & 0.22 & 2.80 & 0.19 & 0.41 & 0.11 & 0.09 \\
\hline & $\operatorname{LSD}_{(0.05)}$ & 0.262 & 1.075 & 0.067 & 0.439 & 0.040 & 0.043 & 0.052 & 0.027 & $\mathrm{~ns}$ & $\mathrm{~ns}$ & ns \\
\hline & $\begin{array}{c}\operatorname{LSD}_{(0.05) \text { variety } X} \\
\text { Fertilizer } \\
\end{array}$ & 0.460 & ns & 0.131 & 0.814 & 0.071 & 0.106 & 0.091 & 0.058 & ns & ns & ns \\
\hline & Variety & & & & & & & & & & & \\
\hline & 'SUWAN-I-SR' & 5.18 & 18.80 & 1.46 & 9.99 & 0.51 & 0.23 & 1.06 & 0.18 & 0.30 & 0.09 & 0.07 \\
\hline & 'Oba 98' & 5.32 & 18.94 & 1.39 & 9.10 & 0.66 & 0.24 & 1.03 & 0.19 & 0.17 & 0.05 & 0.06 \\
\hline Late season & 'Uselu' local & 5.17 & 17.26 & 1.46 & 9.47 & 0.56 & 0.25 & 1.55 & 0.17 & 0.32 & 0.08 & 0.05 \\
\hline 2015 & $\operatorname{LSD}_{(0.05)}$ & 0.064 & ns & ns & ns & $\mathrm{ns}$ & $\mathrm{ns}$ & $\mathrm{ns}$ & ns & ns & 0.015 & 0.005 \\
\hline & Fertilizer type & & & & & & & & & & & \\
\hline & Control & 4.92 & 15.12 & 0.73 & 5.12 & 0.47 & 0.22 & 0.26 & 0.15 & 0.30 & 0.08 & 0.01 \\
\hline & Poultry manure & 5.59 & 22.20 & 1.16 & 8.48 & 0.73 & 0.25 & 1.24 & 0.23 & 0.17 & 0.05 & 0.06 \\
\hline
\end{tabular}


Ahmadu Ret al. (2020). Not Sci Biol 12(1):189-195.

190

\begin{tabular}{|c|c|c|c|c|c|c|c|c|c|c|c|c|}
\hline & Cattle manure & 5.41 & 20.22 & 1.07 & 7.89 & 0.62 & 0.28 & 0.44 & 0.18 & 0.18 & 0.06 & 0.16 \\
\hline & NPK & 4.97 & 15.80 & 2.79 & 16.60 & 0.5 & 0.20 & 2.92 & 0.16 & 0.41 & 0.10 & 0.05 \\
\hline & $\operatorname{LSD}_{(0.05)}$ & 0.234 & 2.927 & 0.169 & 1.095 & 0.132 & 0.039 & 1.061 & 0.035 & 0.111 & 0.016 & 0.009 \\
\hline & $\begin{array}{c}\operatorname{LSD}_{(0.05)} \text { Varicty } X \\
\text { Fertilizer } \\
\end{array}$ & 0.354 & ns & ns & $\mathrm{ns}$ & ns & $\mathrm{ns}$ & ns & ns & 0.203 & 0.026 & 0.015 \\
\hline \multirow{12}{*}{ Combined } & Variety & & & & & & & & & & & \\
\hline & 'SUWAN-I-SR' & 5.15 & 19.21 & 1.44 & 10.70 & 0.53 & 0.25 & 1.06 & 0.17 & 0.43 & 0.13 & 0.09 \\
\hline & 'Oba 98' & 5.23 & 18.67 & 1.42 & 9.14 & 0.6 & 0.25 & 1.02 & 0.19 & 0.22 & 0.06 & 0.08 \\
\hline & 'Uselu' local & 5.13 & 17.32 & 1.48 & 9.61 & 0.53 & 0.24 & 1.34 & 0.19 & 0.30 & 0.07 & 0.08 \\
\hline & $\operatorname{LSD}_{(0.05)}$ & $\mathrm{ns}$ & 0.847 & $\mathrm{~ns}$ & 0.355 & ns & $\mathrm{ns}$ & $\mathrm{ns}$ & $\mathrm{ns}$ & 0.135 & 0.037 & $\mathrm{~ns}$ \\
\hline & Fertilizer type & & & & & & & & & & & \\
\hline & Control & 4.84 & 14.74 & 0.74 & 5.14 & 0.44 & 0.21 & 0.26 & 0.14 & 0.36 &. .01 & 0.01 \\
\hline & Poultry manure & 5.43 & 22.53 & 1.18 & 8.81 & 0.66 & 0.29 & 0.92 & 0.22 & 0.27 & 0.08 & 0.06 \\
\hline & Cattle manure & 5.48 & 20.44 & 1.08 & 7.84 & 0.64 & 0.28 & 0.51 & 0.19 & 0.23 & 0.07 & 0.19 \\
\hline & NPK & 4.99 & 15.90 & 2.78 & 16.64 & 0.48 & 0.21 & 2.86 & 0.18 & 0.41 & 0.10 & 0.07 \\
\hline & $\operatorname{LSD}_{(0.05)}$ & 0.170 & 1.481 & 0.097 & 0.554 & 0.026 & 0.030 & 0.512 & 0.022 & 0.096 & 0.024 & 0.009 \\
\hline & $\begin{array}{c}\operatorname{LSD}_{(0.05)} \text { Variety } \mathrm{X} \\
\text { Fertilizer } \\
\end{array}$ & 0.275 & ns & ns & 0.886 & $\mathrm{~ns}$ & 0.061 & $\mathrm{~ns}$ & 0.045 & ns & ns & ns \\
\hline
\end{tabular}

ns $=$ Not significance

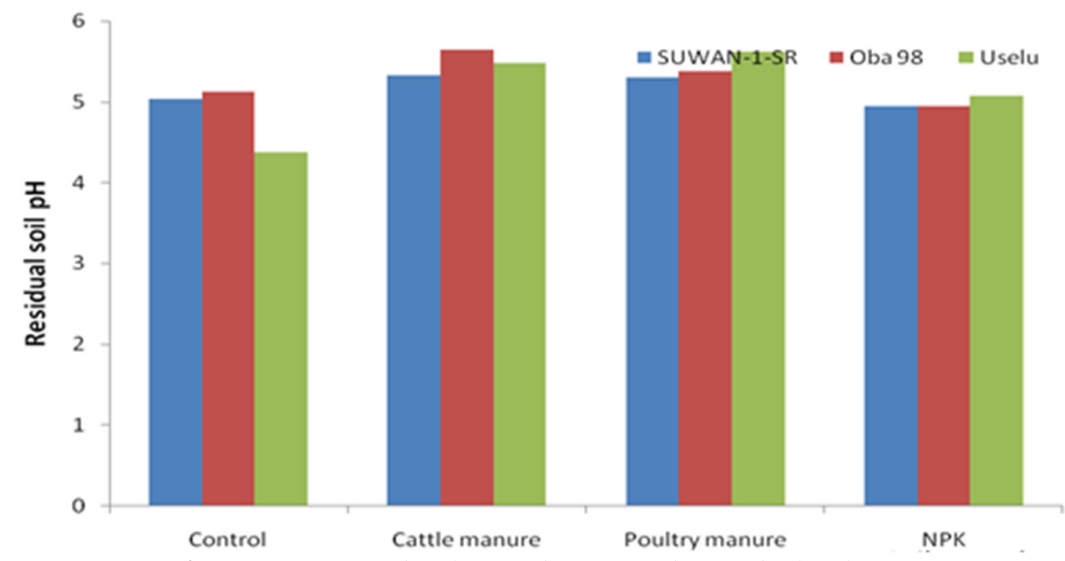

Figure 1. Interaction of maize variety and soil amendment on the residual soil $\mathrm{pH}$

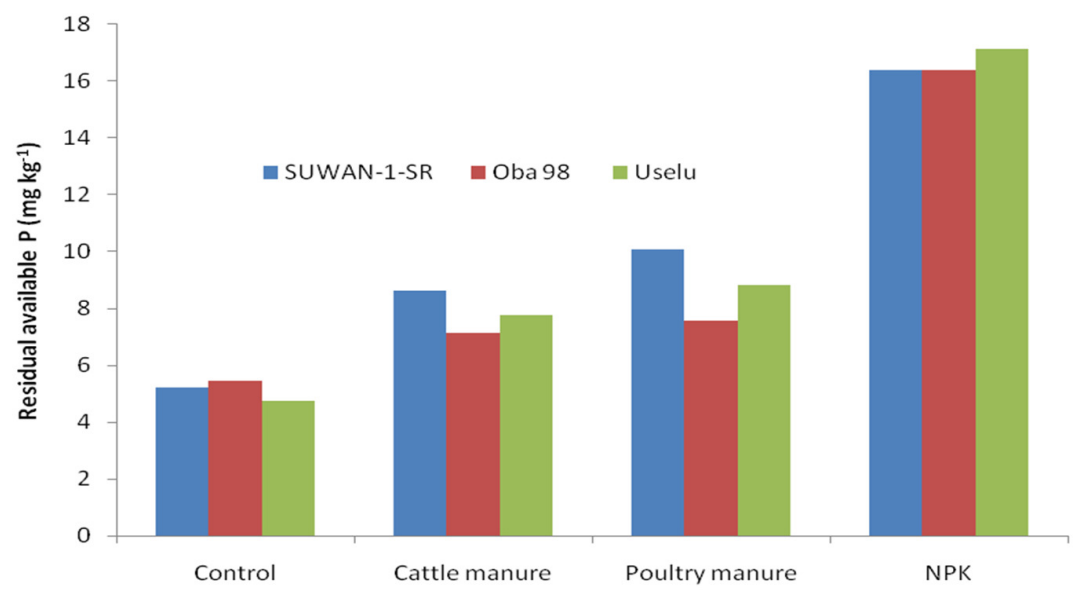

Figure 2. Interaction of maize variety and soil amendment on residual soil available $P$ 


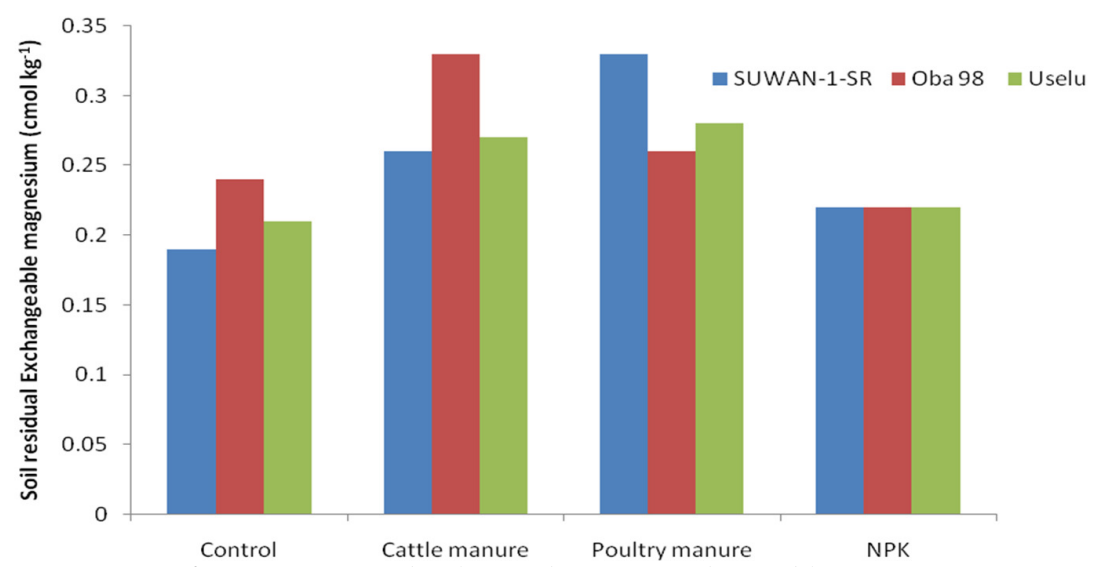

Figure 3. Interaction of maize variety and soil amendment on exchangeable magnesium

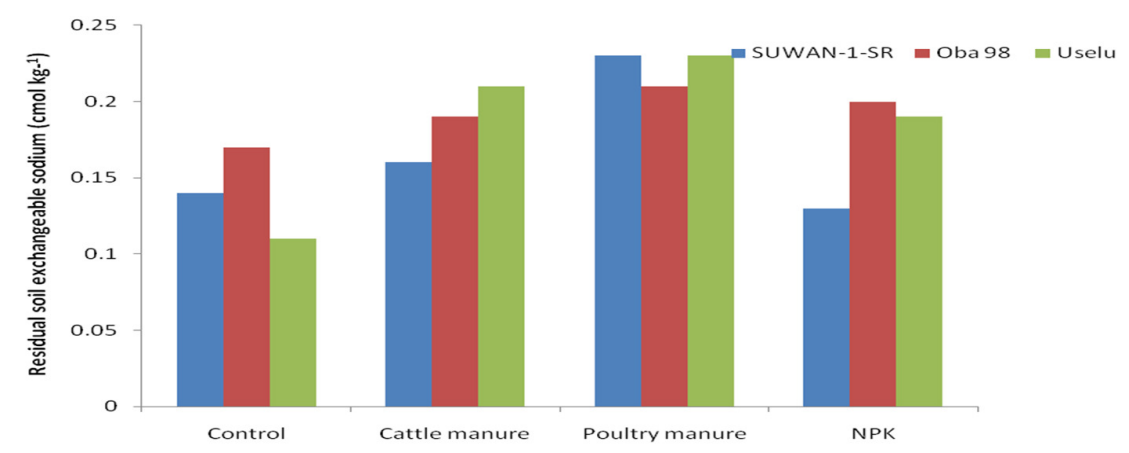

Figure 4. Interaction of maize variety and soil amendment on residual soil exchangeable sodium

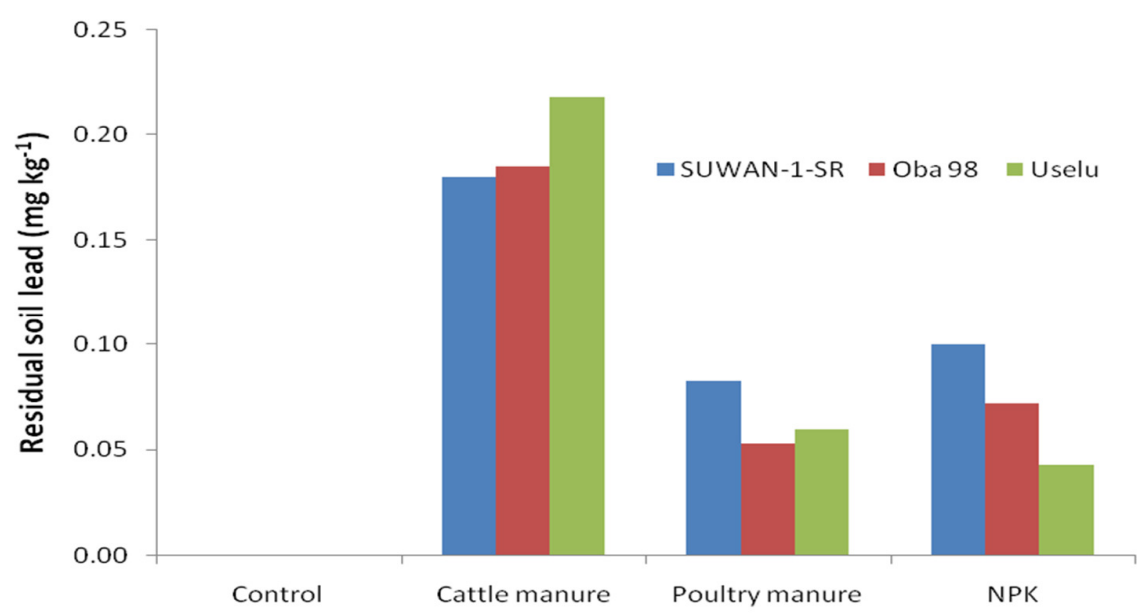

Figure 5. Interaction of maize variety and soil amendment on residual soil lead

\section{Discussion}

The soils of the study sites were of low fertility status evidenced through the exhibition of deficiencies of some essential nutrients (total $\mathrm{N}$, available $\mathrm{P}$ and exchangeable bases $\left(\mathrm{Ca}^{2+}\right.$ and $\left.\mathrm{Mg}^{2+}\right)$. The soil type was a typical ultisols. The effective cation exchange capacity was less than 10 and is acidic sand. The low fertility status of the soil of the experimental site has resulted in low yield per hectare for maize plant without soil 
192

amendment application. This observation is in agreement with Akanbi and Togun (2002) who reported that most of agricultural soils of southern and northern Nigeria are of low fertility status owing to weathering, leaching and intensive cultivation. This implied that reasonable yield could only be achievable through the use of soil amendment and justified the need for augmenting the soil with external fertilizer input in the form of organic (cattle and poultry manures) and inorganic (NPK). An assessment by Stewart et al. (2005) found out that $40-60 \%$ of crop yields are attributed to fertilizer (commercial fertilizer) use. This increase in crop yield could be attributable to the supplementation of nutrients in the soil by nutrient content of the applied fertilizer.

The chemical composition of cattle and poultry manures indicated that they contained essential plant nutrients in appreciable quantity. The high organic carbon content of the organic fertilizer is an indication of abundant organic matter which plays an important role as reservoir of soil nutrients, buffer the soil reaction, binding the soil particles to form good soil and stimulating the activities of soil organisms. Adekayode and Ogunkoya (2010) reported that manures help to improve the soil physical condition and is an indication of being a major contributor of plant nutrients.

In the hereby study, fertilizer application showed a promising result in improving crop productivity. Soil amendment application promote vegetative growth through the enhancement of plant height, stem girth, number of leaves, leaf area index and total dry matter. The high values of plant height and other parameters with organic (poultry and cattle manures) and inorganic (NPK) fertilizers might be due to their synergistic effect of increasing nutrient use efficiencies and special effects of the fertilizers which acted as the store house of plant nutrients. This coincided with the findings of Adekayode and Ogunkoya (2010) who reported that there was a very high significant difference in maize plant height in plots treated with fertilizers compared with no fertilizer application. The observed significant performance in growth parameters with the application of poultry manure, cattle manure and NPK fertilizer could also be attributed to the essential nutrient elements contained in them that are associated with increased photosynthetic efficiency (Agba $e t$ al., 2012). Enhancement of plant height implied more avenue for emergent of leaves. Leaf is an organ of photosynthesis. Any increase in the number of leaves will increase the plant photosynthetic ability and thus enhanced plant growth and vigour. Higher LAI signify greater leaf production rate (Law-Ogbomo et al., 2012). LAI of any plant is a measure of the capacity of the photosynthetic system of translocation. Increase in LAI is an indication of greater light interception. This implied efficient production of assimilates (photosynthate) leading to higher dry matter and economic yield production (Law-Ogbomo et al., 2012).

The study showed higher number of kernels per cob and other parameters of the maize plant on plots treated with soil amendments. This might be due to effects of these fertilizers that improved the nutrient efficiencies and normal development of the maize cob with higher number of kernel rows $\mathrm{cob}^{-1}$, number of kernels row ${ }^{-1}, 1,000$-grain weight and grain yield. Number of kernels $\operatorname{cob}^{-1}$ had direct effect on grain yield of maize per unit area (Haseeb-ur-Rehman et al., 2010). These findings were supported by the observation of N'Dayegamiye et al. (2010) who reported that application of fertilizer led to high maize yields. Rasheed et al. (2004) also found that maximum grain yield of maize was obtained from plots treated with fertilizer. LawOgbomo and Law-Ogbomo (2009) reported that the increased yield associated with fertilized plants was an indication that these soil amendments provided adequate nutrients for optimum plant growth and consequent yield of maize. Increase in stem girth is a reflection of retention of appreciable amount of assimilates in the stem for leaf production (Law-Ogbomo and Law-Ogbomo, 2009).

The reduction in the yield of maize plant observed in samples without fertilizer treatment may be related to insufficient nutrient uptake as the plants had to rely on native fertility of the soil which has been shown to be deficient in total nitrogen, available $\mathrm{P}$ exchangeable cations (calcium and magnesium). The significant grain yield increase obtained by application of fertilizers clearly demonstrated the benefit of the application of fertilizer to the maize plant. Fertilizer application enhanced plant height and LAI. This confirmed the role of soil amendment in promoting vigorous vegetative growth and yield (Ekesiobi $e t$ al., 2015). 
'SUWAN-1-SR' variety exhibited highest plant height, thickest stem, highest LAI, thus indicating superiority of 'SUWAN-1-SR' over 'Oba 98' and 'Uselu' local in terms of growth. This was reflected in the highest number of kernel row $\mathrm{cob}^{-1}$, number of kernels row ${ }^{-1}$ and grain yield. The superiority of 'SUWAN-1SR' variety over 'Oba 98' and 'Uselu' local could be attributed to its genetic potential to excel in that environment. Sanginga et al. (2003) have reported yield differences among crop varieties. They observed that some crop genotypes tend to have greater need for nutrients and are often more responsive to nutrient input.

After cropping, the fertilized plots contained more nutrient reserve than unfertilized plot. This could probably due to enrichment of the soil with added nutrients from applied fertilizers. This is a reflection of plant nutrient availability in organic (cattle and poultry manures) and inorganic (NPK) fertilizers. However, the soil organic carbon was lower in unfertilized plots and NPK treated plots than organic fertilizer treated plots. The organic carbon contents in unfertilized plots and NPK were less than $20 \mathrm{~g} \mathrm{~kg}^{-1}$. An ideal soil should contain $20 \mathrm{~g} \mathrm{~kg}^{-1}$ organic carbon. This emphasized that crop production can be sustained continuously in organic fertilizer treated plots. The exhibition of higher exchangeable acidity by the unfertilized plots is as a reflection of the exhaustion of the soil nutrient and low organic carbon content. The higher soil $\mathrm{pH}$ in plots treated with poultry and cattle manures showed in the present study agreed with Ano and Agwu (2005). The higher $\mathrm{pH}$ associated with organic fertilizer application was probably due to ionic exchange reaction which occurred when terminal $\mathrm{OH}^{-}$of $\mathrm{K}$ or $\mathrm{Al}$ were replaced by organic anions such as tartrate, malate and citrate (Bell and Besho, 1993). The ability of organic fertilizer to increase soil $\mathrm{pH}$ could be attributed to the enrichment of the soil through mineralization of cations particularly calcium.

The content of lead $(\mathrm{Pb})$ in the soil after harvest might have resulted from the inclusion of the soil amendment which led to the $\mathrm{Pb}$ content in the soil. The $\mathrm{Pb}$ concentration in the soil amendment treated plots was within this permissible limit of $2-60 \mathrm{mg} \mathrm{kg}^{-1}$ (Alloway, 1990). Lead was significantly most concentrated in plots treated with cattle manure. This could probably be due to the nomadic rearing of cattle thereby giving them the opportunity to feed and drink water anywhere they are available. This will make them have access to lead $(\mathrm{Pb})$ from contaminated food material.

\section{Conclusions}

The present study has showed that the yield of maize can be increased with soil amendment application and the selection for use of the most promising variety. It was observed that increases in growth and yield parameters were more effective in plants treated with NPK and poultry manure. Also, the effects of varieties on maize growth and yield parameters showed that 'SUWAN-1-SR' variety performed better than 'Oba 98' and 'Uselu' local varieties in the area of study. Higher nutrient residual effect was associated with organic fertilizers, with higher organic carbon control. Based on the hereby findings, 'SUWAN-1-SR' and poultry manure could be adopted by maize growing farmers in the low fertile soil environment.

\section{Acknowledgements}

This research received no specific grant from any funding agency in the public, commercial, or not-forprofit sectors.

\section{Conflict of Interests}

The authors declare that there are no conflicts of interest related to this article. 


\section{References}

Adekayode FO, Ogunkoya MD (2010). Effect of quantity and placement distances of inorganic 15-15-15 fertilizer in improving soil fertility status and the performance and yield of maize in tropical rain forest zone of Nigeria. Journal of Soil Science Environment Management 1(7):155-163.

Agba OA, Ubi BE, Abam P, Ogbech J, Odey S, Ogar N (2012). Evaluation of agronomic performance of maize (Zea mays L.) under different rates of poultry manure application in a ultisol of Obubra, Cross River State, Nigeria. International Journal of Agriculture and Forestry 2(4):138-144.

Akanbi WB, Togun AO (2002). The influence of maize stover compost and nitrogen fertilizer on growth, yield and nutrient uptake of Amaranthus. Scientia Horticulture 93(1):1-8.

Alloway BJ (1990). Heavy metals on soil. John Wiley and Sons. Inc. New York pp 50-280.

Anderson F, Ingram I (1993). Tropical soil biology and fertility. A Handbook of Methods. 2nd ed. CAP International pp 221.

Ano OA, Agwu JA (2005). Effect of animal manure on selected soil chemical properties. Journal of Soil Science 15(1):14-19.

Bell BC, Besho T (1993). Assessment of aluminum detoxification by organic materials in an ultisol using soil solution characterization and plant response. In: Milongoy IC, Rmerck E (Eds). Soil organic matter dynamics and sustainability of tropical agriculture. John Wiley and Sons. New York pp 317-330.

Black CA (1965). Methods of soil analysis. American Society of Agronomy Monograph. Madison, Wisconson.

Bremmer JM, Mulvaney CS (1982). Total nitrogen. In: Page AL (Ed). Methods of soil analysis. Part 2. Chemical and microbial properties, 2nd ed, Agronomy Series, Madison, WI, USA, ASA, SSSA pp 9.

Day PR (1965). Particle fractionating and particle size analysis. In: Methods of soil analysis. Part 1. Agronomy 9:549552.

Ekesiobi LA, Ndukwe OO, Ezeano CL, Odukwe KA, Nnabuife ELC (2015). Influence of complementary rate of poultry manure and urea fertilizers on growth and yield of maize (Zea mays L.) in South Eastern agro-ecology zone. International Journal of Applied Science and Engineering 3(1):8-13.

Food and Agricultural Organization (FAO) (2009). Maize, rice and wheat; area harvested, production, quantity, yield. FAO of the United Nations, Statistics Division.

Gee GW, Or D (2002). Particle size analysis. In: Dane JH, Topp GC (Eds). Methods of soil analysis. Part 4. Physical methods. Soil Science Society of America. Book series No. 5. Madison, WI pp 255-293.

GENSTAT (2005). Genstat Release 8.1. Statistical Software. VSN, International Limited. Rothamsted UK.

Haseeb-ur-Rehman A, Ali M, Waseem A, Tanveer M, Nadeem MA, Zamir MSI (2010). Impact of nitrogen application on growth and yield of maize (Zea mays L.) grown alone and in combination with cowpea (Vigna unguiculata L.) American Eurasian Journal of Agriculture and Environmental Science 7(1):43-47.

Houba VJG, Temminghoff EM, Gaikhorst GA, Van Vark W (2000). Soil analysis procedures using $0.01 \mathrm{M} \mathrm{CaCl} 2$ as extraction reagent. Community Soil Science and Plant Analysis 31(9-10):1299-1396.

Law-Ogbomo KE, Law-Ogbomo JE (2009). The performance of Zea mays L. as influenced by NPK fertilizer application. Notulae Scientia Biologicae 1(1):59-62.

Law-Ogbomo KE, Remison SU, Jombo EO (2012). Effect of organic and inorganic fertilizer on the productivity of Amaranthus cruentus. Nigerian Journal of Agriculture, Food and Environment 8(2):35-40.

Mohamed E, Hassan A (2011). Effect of different nitrogen sources on growth, yield and quality of fodder maize (Zea mays L.). Journal of the Saudi Society of Agricultural Sciences 10(1):17-23.

N’Dayegamiye A, Drapeau A, Nduwamungu C (2010). Fresh and composted paper sludges sustain soil productivity. International Journal of Agronomy 132080:1-10.

Ojeniyi SO (2000). Effects of goat manure on soil physical properties and okra yield in a rainforest area of Nigeria. Applied Tropical Agriculture 5:20-23.

Page AL (1982). Methods of soil analysis. Agronomy No. 9. Part 2. American Society of Agronomy. Madison, Winsconsin.

Rasheed M, Ali H, Mahmood T (2004). Impact of nitrogen and sulfur application on growth and yield of maize (Zea mays L.) crop. Journal of Research Science 2(2004):153-157.

Sanginga N, Dashiell KJ, Diels J, Vanlauwe B, Lyasse OR, Carsky RJ, ... Rodomiro OD (2003). Sustainable resource management coupled with resilient germplasm to provide new intensive cereal-grain legume - livestock systems in the dry savanna. Agriculture, Ecosystems and Environmental 100:305-314. 
Somani LL, Totawat KL (1996). Soil conditioners and amendments. Agrotech. Publication Academy, 1st ed. Udaipur pp 28-160.

Stefano P, Dris R, Rapparim F (2004). Influenced of growing conditions and yield and quality of cherry. II. Fruit. Journal of Agriculture and Environmental 2:307-309.

Stewart ET, Madden R, Paul G, Taddei F (2005). Aging and death in an organism that reproduces by morphologically symmetric division. PLoS Biology 3(2):e45.

OPEN ACCESS

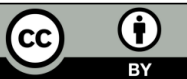

The journal offers free, immediate, and unrestricted access to peer-reviewed research and scholarly work, due SHST supports to increase the visibility, accessibility and reputation of the researchers, regardless of geography and their budgets. Users are allowed to read, download, copy, distribute, print, search, or link to the full texts of the articles, or use them for any other lawful purpose, without asking prior permission from the publisher or the author.

License - Articles published in Notulae Scientia Biologicae are Open-Access, distributed under the terms and conditions of the Creative Commons Attribution (CC BY 4.0) License.

(C) Articles by the authors; SHST, Cluj-Napoca, Romania. The journal allows the author(s) to hold the copyright/to retain publishing rights without restriction. 